\title{
Origin, evolutionary classification, and biostratigraphic of the Late Cretaceous planktic foraminiferal directional lineage Bollitruncana O.A. Korchagin, 2001
}

\author{
M. Dan GEORGESCU \\ Department of Geosciences, University of Calgary, 2500 Northwest Drive, Calgary, Alberta T2N 1N4, Canada
}

Received December 2011; accepted May 2012

Available online 25 May 2012

DOI: $10.5038 / 1937-8602.57 .2 .1$

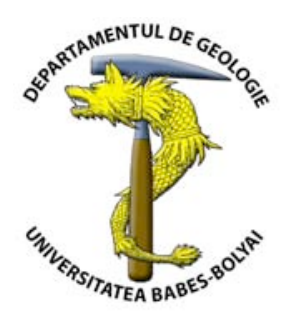

Abstract. Taxonomic revision of the genus Bollitruncana O.A. Korchagin, 2001 shows that it accommodates a directional lineage, which consists of two species: B. carpathica (Scheibnerová, 1963) and B. posthelvetica (Hanzliková, 1963). Bollitruncana directional lineage is restricted to Turonian. A new planktic foraminiferal biozone is recognized in the Turonian, namely the Bollitruncana carpathica Biozone.

Key words: planktic foraminifers, Late Cretaceous, taxonomy, evolution, biostratigraphy.

\section{INTRODUCTION}

Cretaceous planktic foraminifera with truncated periphery, peripheral structures consisting of one or two keels and periapertural structures consisting of portici and/or tegilla are included into the large informal globotruncanid group; the group is known from the Turonian-Maastrichtian stratigraphic interval. The planktic foraminifers with globotruncanid appearance of the Turonian are included into two genera: partly Dicarinella Porthault in Donze et al., 1970 (late Cenomanian-Santonian), Marginotruncana Hofker, 1956 (middle Turonian-early Campanian) in the classical in-use typological classification (Robaszynski and Caron, 1979; Robaszynski et al., 1984; Caron, 1983, 1985; Loeblich and Tappan, 1988).

A more detailed and elaborate typological classification of the globotruncanid group was produced by Korchagin (1982) and Korchagin $(2001,2003)$. Although much of the significant taxonomic criterion weight falls on the test periphery, this new framework refined the taxonomic units at genus rank. This represented a major leap in producing an evolutionary classification framework for the Late
Cretaceous globotruncanid foraminifera, which is an ongoing process in the heterohelicid, hedbergellid and praeglobotruncanid planktics. An excellent example is represented by the "single-keeled" marginotruncanids, which were included into genus Bollitruncana O.A. Korchagin, 2001. The taxonomic revision of this genus is necessary in order to test if it can be defined as lineage, which is a unit with significance in evolutionary classification (Georgescu, 2009a).

\section{MATERIAL AND STUDIED}

The material used in this study was collected from three Deep Sea Drilling Project/Ocean Drilling Program wells: DSDP Site 463 (Mid-Pacific Mountains, Central Pacific Ocean), ODP Hole 762C (Exmouth Plateau, Eastern Indian Ocean) and ODP Hole 1050C (Blake Plateau, Western North Atlantic Ocean) (Fig. 1). The samples from which the specimens were collected are labeled according to the DSDP/ODP rules as follows: leg number-site/hole number-core number-section number, sample depth given in centimeters.

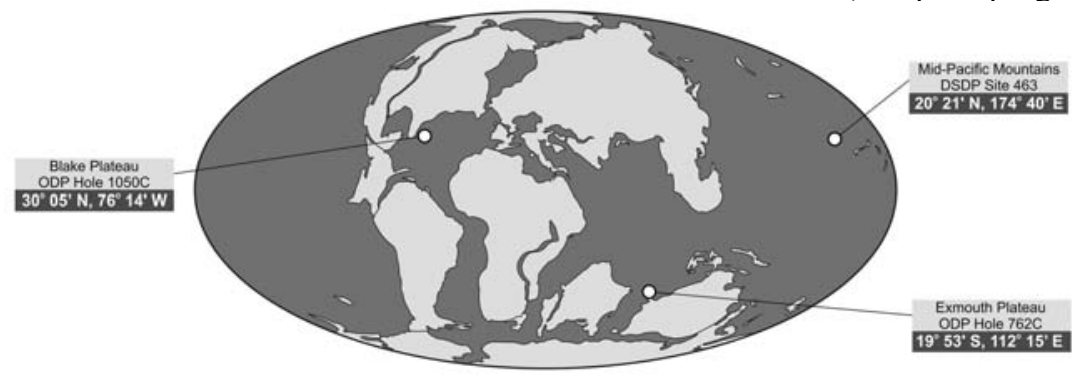

Fig. 1. Geographical location of the three DSDP/ODP sections that yielded the fossil material used in this study. Base map is a reconstruction at 100 m.y. (after Hay et al., 1999, with modifications).

A continuous sedimentation across the Cenomanian/Turonian boundary and throughout the Turonian is recorded in the ODP Hole 762C. Clayey nannofossil chalks are recorded in the upper Cenomanian sediments (core 75, section 2); the clay content gradually decreases upwards and therefore, nannofossil chalks occur in the Turonian sediments (Shipboard Scientific Party, 1990). Two Cretaceous planktic foraminiferal biostratigraphic frameworks were given by Wonders (1992) and Petrizzo $(2000,2001)$, and they are 
refined herein based on extensive high resolution SEM observations. A succession of five planktic foraminiferal biozones is recorded in the interval between the base of core 75 and core 73 , section 2 (Table 1). Rotalipora cushmani Biozone is recorded in the Cenomanian; the Cenomanian/Turonian boundary is defined by the first occurrence (FO) of Whiteinella archaeocretacea Pessagno, 1967. The last occurrence LO of $W$. archaeocretacea and FO of B. carpathica occur in two successive samples; the $B$. carpathica Biozone is herein defined as interval zone between the FO of the index species and the FO of Helvetoglobotruncana helvetica (Bolli, 1945). The uppermost biozone in the lower Turonian is the $H$. helvetica Biozone, a taxon range zone. The occurrences of Marginotruncana coronata (Bolli, 1945) and M. renzi (Gandolfi, 1942) in the sample above the LO of $H$. helvetica, namely in the sample $122-762 \mathrm{C}-73-2,20-21 \mathrm{~cm}$, apparently indicate a late Turonian age. The planktic foraminiferal tests collected from the upper Cenomanian-Turonian sediments are well-preserved, allowing accurate observations on the test ultrastructure, ornamentation and porosity; all the tests present the low magnitude recrystallization that frequently occurs in the deep oceanic nannofossil chalks.

Table 1. Planktic foraminiferal occurrences and stratigraphic distribution in the upper Cenomanian-Turonian sediments of the ODP Hole 762C (Exmouth Plateau, Eastern Indian Ocean).

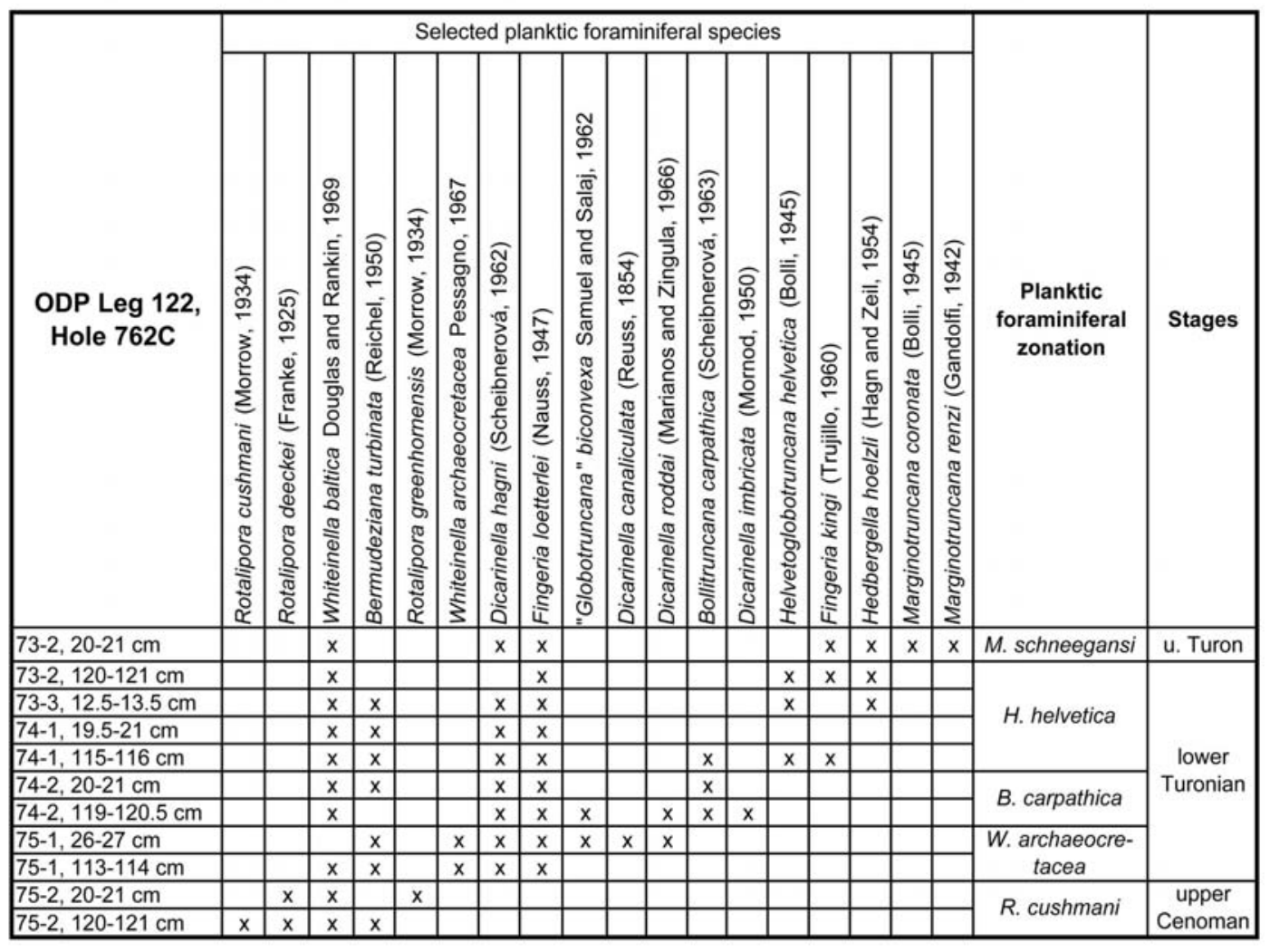

A continuous Late Cretaceous (Aptian-Maastrichtian) sedimentation was recognized by Boersma (1981) at DSDP Site 463. The continuous sedimentation was confirmed for the Turonian-middle Campanian stratigraphic interval (Georgescu, 2010a, 2011; Georgescu et al., 2011). The study between the cores 43 and 33 at this site shows the occurrence of three biozones in the upper Cenomanian-Turonian stratigraphic interval (Table 2). Rotalipora globotruncanoides Biozone is defined by a planktic foraminiferal assemblage that occurs between cores 43 and 38, and in which the species Thalmanninella brotzeni Sigal, 1948, R. globotruncanoides Sigal, 1948 and $R$. greenhornensis (Morrow, 1934) are the dominant species. The occurrence of $H$. helvetica in the sample situated immediately above that with the youngest rotaliporid specimens indicates that there is an unconformity that spans the $W$. archaeocretacea and B. carpathica Biozones. Therefore, $H$. helvetica Biozone is defined as the stratigraphic interval with the index species, between its FO and LO; the latter bioevents is recorded in core 34, section 1 . The consistent occurrences of the species M. sigali (Reichel, 1950) and M. schneegansi (Sigal, 1952) throughout core 33 indicate a late Turonian age. The planktic foraminiferal assemblages are well preserved; however, all the specimens examined present low magnitude recrystallization.

ODP Hole 1050C intersected a stack of Cretaceous sediments, which spans the upper Albian-Maastrichtian stratigraphic interval (Shipboard Scientific Party, 1998; Huber et al., 1999, 2008; Bellier and Moullade, 2002; Petrizzo and Huber, 2006; Georgescu, 2009a, b, Georgescu and Huber, 2009). The Turonian sediments are dominated by nannofossil chalks occur in the upper part of core 21 and core 20, excepting for its uppermost part; an unconformity spanning the latest Cenomanian-earliest Turonian is recorded across the Cenomanian/Turonian boundary. Two biozones are recognized in the Turonian sediments: $B$. carpathica at the base and $H$. helvetica above it (Table 3). The former is defined from the unconformity to the FO of $H$. helvetica; $H$. helvetica Biozone is developed between the FO and LO of the index species. The uppermost three samples in the Turonian succession, which are situated above the LO of $H$. helvetica, lack the index species Marginotruncana schneegansi or any other with higher stratigraphical first occurrences, and therefore are only tentatively conferred a late Turonian age. A hiatus spanning the late Turonian and at least early Coniacian is recorded in the uppermost part of core 20; the occurrence of Contusotruncana fornicata (Plummer, 1931) in the sample 171B-1050C-20-1, 42$45 \mathrm{~cm}$, indicates at least a late Coniacian age for overlying sediments. Foraminiferal tests are well-preserved, although affected by small magnitude recrystallization. 
Table 2. Planktic foraminiferal occurrences and stratigraphic distribution in the upper Cenomanian-Turonian sediments of the DSDP Site 463 (Mid-Pacific Mountains, Central Pacific Ocean).

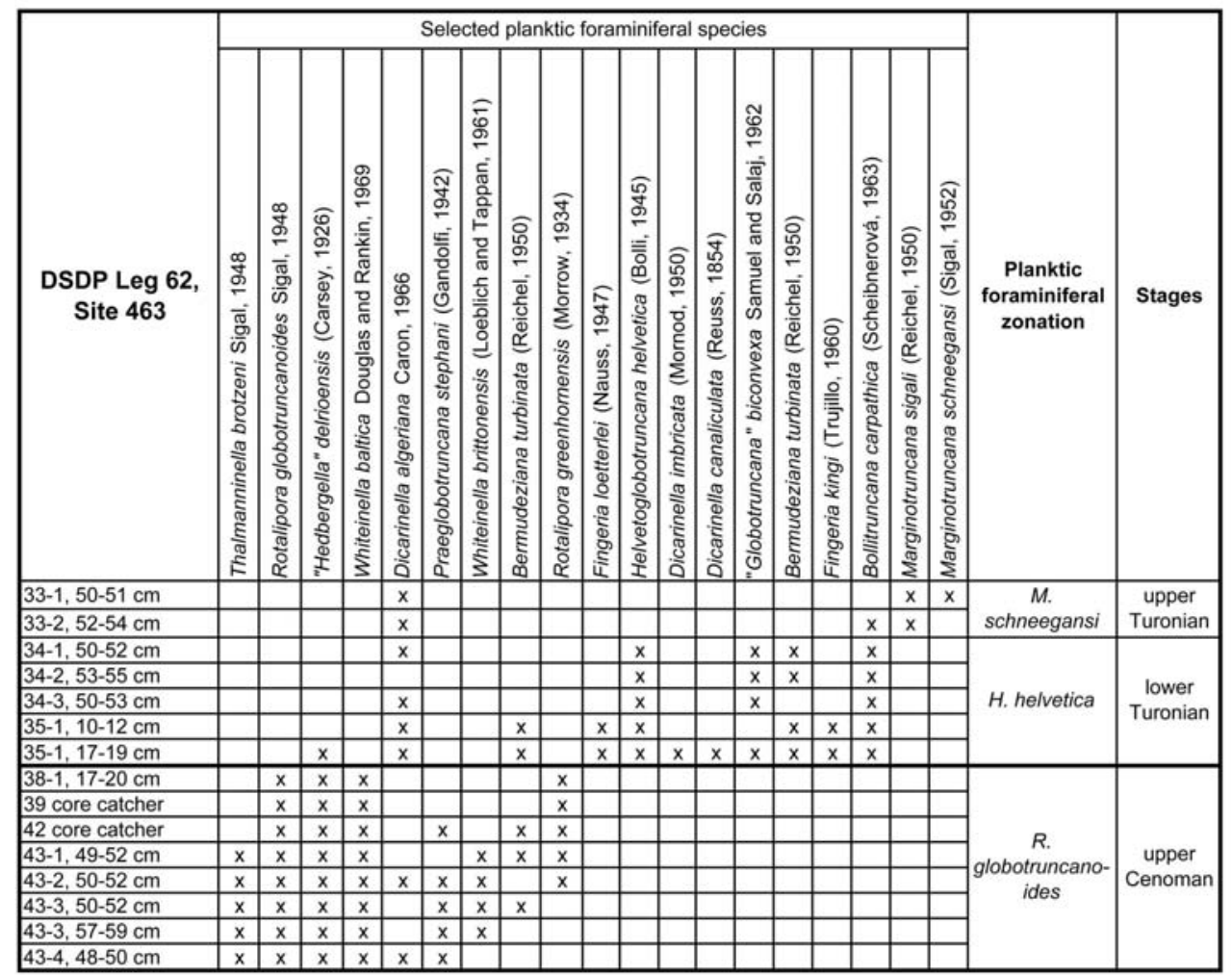

Table 3. Planktic foraminiferal occurrences and stratigraphic distribution in the upper Cenomanian-Turonian sediments of the ODP Hole 1050C (Blake Plateau, Western North Atlantic Ocean).

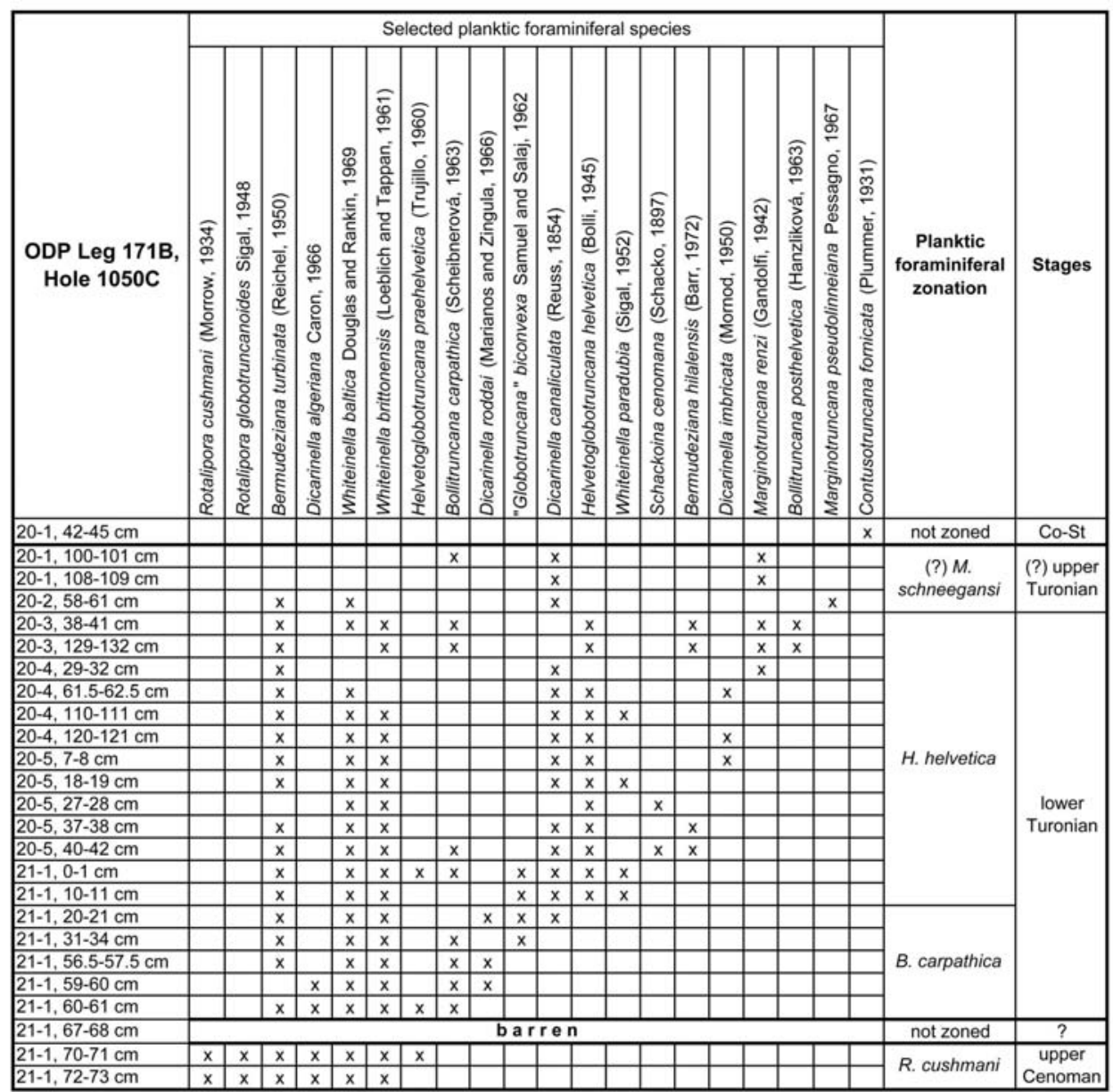

Studia UBB Geologia, 2012, 57 (2), 3 - 16 


\section{SYSTEMATIC DESCRIPTIONS}

Evolutionary classification units are after Georgescu (2009b, 2010b).

Order Foraminiferida Eichwald, 1830

Directional lineage Bollitruncana O.A. Korchagin, 2001 emended

Type species: Bollitruncana elata (Lamolda, 1977a); junior synonym of B. carpathica (Scheibnerová, 1963).

Bollitruncana O.A. Korchagin, 2001, p. 68.

Bollitruncana O.A. Korchagin. O.A. Korchagin, 2003, p. 35.

Emended diagnosis. Turonian globotruncanid lineage with one-keeled periphery, main aperture bordered by an imperforate porticus, ornamentation consisting of scattered pustules and test wall simple and perforate.

Emended description. Test is low to medium high trochospiral. Earlier chambers are globular or subglobular, those of the final whorl crescentic to petaloid on the spiral side and subtrapezoidal on the umbilical side. Sutures on the spiral side are raised and curved, those on the umbilical side distinct, depressed, radial and straight or slightly curved. Text shape is biconvex in edge view, symmetrical in the initiating species and asymmetrical in the first descendant species. Periphery is angular-pinched throughout in the initiating species and with a nearly right peripheral angle at the level of the last-formed chamber, resulting in a planoconvex appearance in edge view in the first descendant species; one peripheral keel, which consists of pustules that can fuse to form axially elongate structures, is developed on all the chambers of the final whorl. Umbilicus is deep, with a diameter of circa one third to one half of the maximum test diameter; weak periumbilical ridges, which are more prominent on the earlier chambers, occur occasionally. Main aperture is a medium-high arch in extraumbilical-umbilical position; aperture is bordered by an imperforate porticus that is attached to the previous chambers across the umbilical region. Chamber surface is ornamented with dome-like or more rarely irregular scattered pustules, which are denser on the earlier chambers on both spiral and umbilical side. Test wall is calcitic, hyaline simple and perforate; pores are circular, rarely elliptical.

Remarks. Genus Bollitruncana is emended in the evolutionary classification to accommodate a directional lineage, which consists of two species: B. carpathica (Scheibnerová, 1963) and B. posthelvetica (Hanzliková, 1963); the former is the lineage initiating species and the latter its first and only descendant. Bollitruncana differs from Marginotruncana Hofker, 1956 (Turonian-Campanian in age) mainly by having the periphery with one keel rather than two; however, Marginotruncana is a conglomerate of lineage, which requires re-evaluation in evolutionary classification. Bollitruncana differs from Helvetoglobotruncana Reiss, 1957 of the late Cenomanian-Turonian mainly by having (i) weaker ornamentation consisting of scattered pustules, (ii) inflated rather than subglobular chambers on the umbilical side, and (iii) periapertural structures consisting of imperforate portici that attach to the previous chambers across the umbilical region. Globotruncanita Reiss, 1957 (late Coniacian-Maastrichtian) is almost a homeomorph of Bollitruncana; the species of Globotruncanita present either periumbilical ridges, or sutural ridges on the umbilical side, or both of them, whereas only weak periumbilical ridges occur occasionally in the species of Bollitruncana; the stratigraphic ranges of the two species do not overlap.

Stratigraphic range. Turonian (from the B. carpathica Biozone throughout the lower part of $M$. schneegansi Biozone).

Geographic distribution. Cosmopolitan.

Bollitruncana carpathica (Scheibnerová, 1963) - emended (Pl. I, Figs 1-7, Pl. II, Figs 1-5, Pl. III, Figs 1-9)

Globotruncana carpathica Scheibnerová, 1963, p. 140, text-fig. 2. Globotruncana marianosi Douglas, 1969, p. 183, pl. 2, fig. 3 , text-fig. 5 .

Globotruncana marianosi Douglas. Douglas, 1970, p. 20, pl. 3, fig. 1.

Dicarinella elata Lamolda, 1977a, p. 471, pl. 1, fig. 1, pl. 2, fig. 3, text-fig. 4.

Dicarinella elata Lamolda. Lamolda, 1977b, p. 391, pl. 1, fig. 4. Praeglobotruncana carpathica (Scheibnerová). Ion, 1983, p. 102, pl. 48, fig. 3.

non Dicarinella sp. cf. Praeglobotruncana elata (Lamolda). González Donoso and Linares in Robaszynski et al., 1990, pl. 38, fig. 4.

Sigalitruncana marianosi (Douglas). González Donoso and Linares in Robaszynski et al., 1990, pl. 38, fig. 5.

Marginotruncana sp. cf. Sigalitruncana marianosi (Douglas). González Donoso and Linares in Robaszynski et al., 1990, pl. 38, fig. 6.

non Dicarinella elata Lamolda. Tur et al., 2001, fig. 12: 6-7. non Dicarinella elata Lamolda. Petrizzo, 2001, fig. 8: 1.

Bollitruncana elata (Lamolda). O.A. Korchagin, 2003, pl. 7, figs 1-3.

Emended diagnosis. Bollitruncana with angular-pinched periphery throughout.

Emended description. Test is low to medium high trochospiral, and consists of 15-21 chambers arranged in 3-3 $1 / 2$ whorls; there are 6-7 chambers (commonly $61 / 2$ ) in the final whorl; chambers present a slow size increase. Earlier chambers are globular or subglobular; the earlier chambers of the final whorl on the spiral side are crescentic, and the last-formed ones petaloid; chambers on the umbilical side are subtrapezoidal. Sutures on the spiral side are raised and curved, those on the umbilical side depressed, radial, straight or slightly curved. Test shape is biconvex, with the umbilical side slightly more convex than the umbilical one; periphery is angular-pinched throughout, and with one wide peripheral keel consisting of closely spaced and partly fused pustules. Umbilical region is deep, and with a diameter representing circa one third to one half of the maximum test diameter. Main aperture is a medium high arch in extraumbilical-umbilical position, and is bordered by an imperforate porticus, which is attached to the previous chambers across the umbilical region; relict periapertural structures frequently occur in the umbilicus. Chamber surface is ornamented with scattered dome-like or irregular pustules (5.5-16.8 $\mu \mathrm{m}$ in maximum dimension), which are denser over the earlier chambers, and can fuse to form irregular rugosities; pustule agglomeration occasionally 
occur around the umbilical region, resulting in the formation of weak periumbilical ridges. Test wall is calcitic, hyaline, simple and perforate; pores are circular, with a diameter of 1.3-5.1 $\mu \mathrm{m}$, rarely elliptical in shape.

Dimensions. Maximum test diameter: $\mathrm{D}_{\max }=0.746-0.836 \mathrm{~mm}$, minimum test diameter: $\mathrm{D}_{\min }=0.600-0.680 \mathrm{~mm}$, $\mathrm{D}_{\min } / \mathrm{D}_{\max }=0.775-0.879$, thickness: $\mathrm{T}=0.365-0.422 \mathrm{~mm}$, $\mathrm{T} / \mathrm{D}_{\max }=0.472-0.542$, umbilical diameter: $\mathrm{UD}=0.316-0.356$ $\mathrm{mm}, \mathrm{UD} / \mathrm{D}_{\max }=0.402-0.425$; peripheral angle: $\mathrm{PA}=62-77^{\circ}$. Ranges based on the average measurements of 12 hypotypes.

Remarks. This species differs from Helvetoglobotruncana helvetica (Bolli, 1945) mainly by having (i) raised sutures between all the chambers on the spiral side, (iii) angularpinched rather than at right angle periphery, and (iii) main aperture bordered by a porticus, which is attached to the previous chambers across the umbilicus, rather than remaining unattached in the umbilical region. The holotype illustrated by Scheibnerová (1963, text-fig. 2) shows a distinct globotruncanid appearance, which cannot be included in Helvetoglobotruncana Reiss, 1957 as considered by Robaszynski and Caron $(1979$, p. 39, 42); the rather narrow keel is herein considered a drawing imperfection, which frequently occurred in the pre-SEM illustrations of many authors (Fig. 2). However, the wide peripheral keel in the original illustrations of D. elata (Lamolda, 1977a) is identical to that in the material included in this study. The holotype of G. marianosi (Douglas, 1969, text-fig. 5) clearly presents traces of dissolution on the umbilical side, but the periumbilical ridges are in the range of development observed in this study; the paratype of $G$. marianosi illustrated by Douglas (1969, pl. 2, fig. 3) is not even congeneric, and most likely belongs to a species of Globotruncanita Reiss, 1957. The Scheibnerová Collection was partly destroyed and will be subject of reevaluation (Dr Stefan Josza, Comenius University, Bratislava - personal communication).
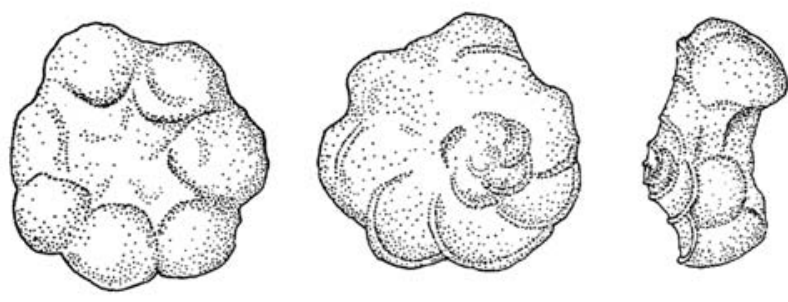

Fig. 2. The holotype of Bollitruncana carpathica (Scheibnerová, 1963); specimen illustrated by Scheibnerová (1963, text-fig. 2). Specimen dimensions: $D_{\max }=0.705 \mathrm{~mm}, D_{\min }=0.655 \mathrm{~mm}, T=0.504 \mathrm{~mm}$.

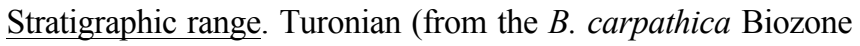
throughout the lower part of $M$. schneegansi Biozone).

Geographic distribution. Cosmopolitan.

Bollitruncana posthelvetica (Hanzliková, 1963) - emended (P1. IV, Figs 1-8, P1. V, Figs 1-8)

Globotruncana helvetica posthelvetica Hanzliková, 1963, p. 325 , pl. 1, figs $1-4$.

Globotruncana sp. A. Marianos and Zingula, 1966, p. 341, pl. 39, fig. 1. Globotruncana carpathica Scheibnerová. Scheibnerová, 1968 , p. 68, pl. 12, fig. 4.

Globotruncana carpathica Scheibnerová. Sturm, 1969, pl. 10, fig. 5. Marginotruncana marianosi (Douglas). Robaszynski and Caron, 1979, p. 115, 118, pl. 65, figs 1-2.
Carpathoglobotruncana marianosi (Douglas). Ion, 1983, p. 112, pl. 48, figs 1-2.

Marginotruncana marianosi (Douglas). Caron, 1985, p. 61, fig. 26: 5-6. Sigalitruncana marianosi (Douglas). Grosheny et al., 1992, pl. 1, figs 1-9.

Marginotruncana marianosi (Douglas). Wonders, 1992, pl. 4, figs 5-6. non Marginotruncana marianosi (Douglas). Petrizzo, 2000, p. 498, fig. 16: 5 .

non Sigalitruncana marianosi (Douglas). Tur et al., 2001, fig. 13: 13.

Emended diagnosis. Bollitruncana with periphery at a right angle at the level of the last-formed chamber.

Emended description. Test is low to medium high trochospiral, consisting of 19-25 chambers arranged in $3 \frac{1}{2}$ $4 \frac{1}{2}$ whorls; there are $6 \frac{1}{2}-7$ (commonly 7 ) chambers in the final whorl; chambers present a slow size increase. Earlier chambers are globular or subglobular; the earliest one or more rarely two chambers in the final whorl are crescentic, and the remaining ones in the final whorl petaloid; chamber shape on the umbilical side is subtrapezoidal. Sutures on the spiral side are raised and curved; sutures on the umbilical side are distinct, depressed, radial and straight or slightly curved. Test shape is asymmetrically biconvex, with the umbilical side distinctly more convex than the spiral one; periphery is angular, and with a nearly right peripheral angle at the level of the last-formed chamber, resulting in a planoconvex appearance in edge view. There is one well-developed wide peripheral keel on all the chambers of the last whorls; the keel consists of pustules, which can fuse to form occasionally elongate structures with axial orientation. Umbilicus is deep, and with a diameter of circa one third to one half of the maximum test diameter. Main aperture has a medium high arch shape, and is situated in extraumbilical-umbilical position; it is bordered by a delicate porticus, which attached to the previous chambers across the umbilical region; relict periapertural structures frequently occur in the umbilicus. Chamber surface is ornamented with scattered dome-like or irregular pustules (7.8$17.6 \mu \mathrm{m}$ in maximum dimensions), which are denser over the earlier chambers on both test size; pustules can fuse to form elongate rugosities (22.0-26.5 $\mu \mathrm{m}$ in length). Pustule agglomerations occur around the umbilicus, resulting in the occasional formation of weak periumbilical ridges; the pustules in the periumbilical ridges are not completely fused. Test wall is calcitic, hyaline, simple and perforate; pores are circular, and with a diameter of 2.3-5.7 $\mu \mathrm{m}$; pores with elliptical shape occur occasionally.

Dimensions. $\quad \mathrm{D}_{\max }=0.724-0.892 \mathrm{~mm}, \mathrm{D}_{\min }=0.641-0.710 \mathrm{~mm}$, $\mathrm{D}_{\min } / \mathrm{D}_{\max }=0.769-0.879, \mathrm{~T}=0.398-0.487 \mathrm{~mm}, \mathrm{~T} / \mathrm{D}_{\max }=0.466-0.580$, $\mathrm{UD}=0.286-0.387 \mathrm{~mm}, \quad \mathrm{UD} / \mathrm{D}_{\max }=0.395-0.433, \quad \mathrm{PA}=86-104^{\circ}$. Ranges based on the average measurements of 12 hypotypes.

Remarks. Bollitruncana posthelvetica differs from $B$. carpathica by having (i) the test consisting of more chambers (19-25 rather than 15-21), (ii) lower trochospire, and (iii) higher peripheral angle $\left(86-104^{\circ}\right.$ rather than $\left.62-77^{\circ}\right)$; it differs from $M$. sigali mainly by the (i) higher peripheral angle resulting in a plano-convex appearance, (ii) less developed periumbilical ridges, and (iii) subtrapezoidal rather than subrectangular chamber shape on the umbilical side; it differs from $M$. schneegansi mainly by the (i) higher peripheral angle resulting in plano-convex appearance, and (ii) more inflated chambers on the umbilical side. Hanzliková (1963) did not provide a repository of the specimens used in the original description of B. posthelvetica. Two re-illustrated specimens from the original figuration (Fig. 3) show the distinct globotruncanid appearance of the species in the Bollitruncana directional lineage; therefore 
the previous taxonomic solution by Robaszynski and Caron (1979, p. 39, 42) according to which $B$. posthelvetica was considered junior synonym of $H$. helvetica (Bolli, 1945) cannot be accepted as based on facts. Bollitruncana posthelvetica is the end species of the Bollitruncana lineage (Fig. 4), which evolved from Bermudeziana Georgescu, 2012; it presents the best developed feature characteristically developed in this lineage, namely the higher peripheral angle (Fig. 5).

Stratigraphic range. Lower Turonian (uppermost part of the $H$. helvetica Biozone).

Geographic distribution. Cosmopolitan.

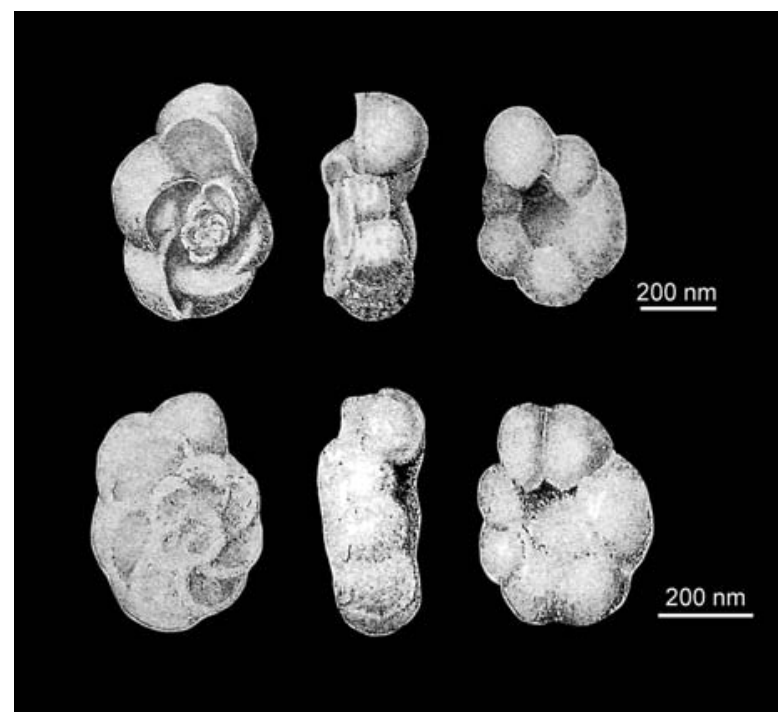

Fig. 3. Two of the type specimens of Bollitruncana posthelvetica (Hanzliková, 1963); above-holotype illustrated by Hanzliková (1963, pl. 1, fig. 1); below-one paratype illustrated by Hanzliková (1963, pl. 1, fig. 4).

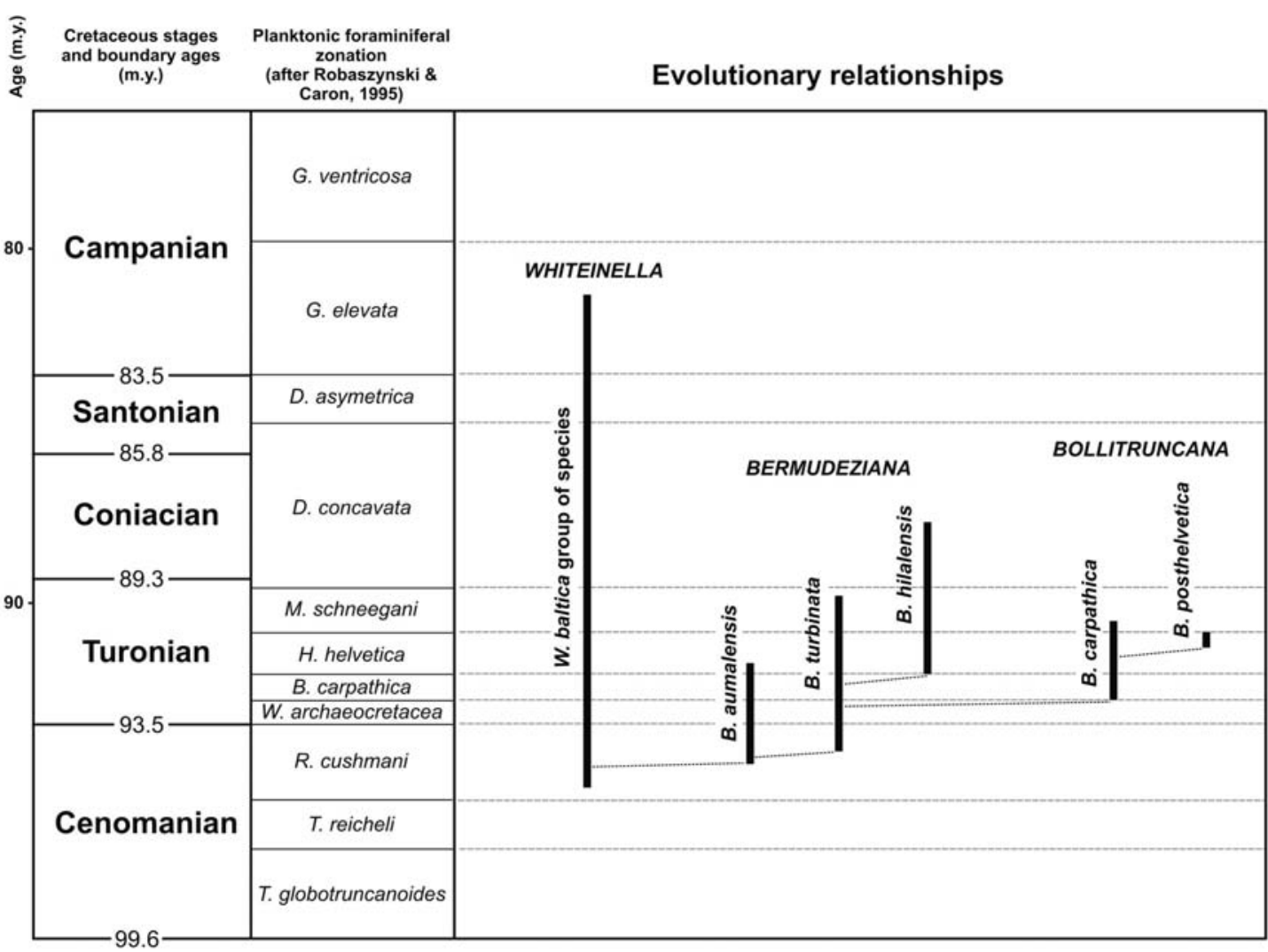

Fig. 4. Origin and evolutionary relationships of the directional lineage Bollitruncana. Ages are after Gradstein et al. (2004). Planktic foraminiferal zonation is modified to accommodate the newly recognized B. carpathica Biozone.

\section{CONCLUSIONS}

Taxonomic revision in evolutionary classification of the genus Bollitruncana O.A. Korchagin, 2001 shows that it represents a directional lineage, which consists of two species: B. carpathica (Scheibnerová, 1963) as initiating species, and its descendant $B$. posthelvetica (Hanzliková, 1963). The lineage is of Turonian age. The species included in Bollitruncana present tests with one wide peripheral keel consisting of fused pustules, which can form axially elongate structures; main aperture is in extraumbilical-umbilical position, and bordered by an imperforate porticus that can be attached of the previous chambers across the umbilical region; periumbilical ridges occur occasionally in both species included in this lineage. The main evolutionary trend in this lineage is the peripheral angle increase, especially in the test last formed chambers. 


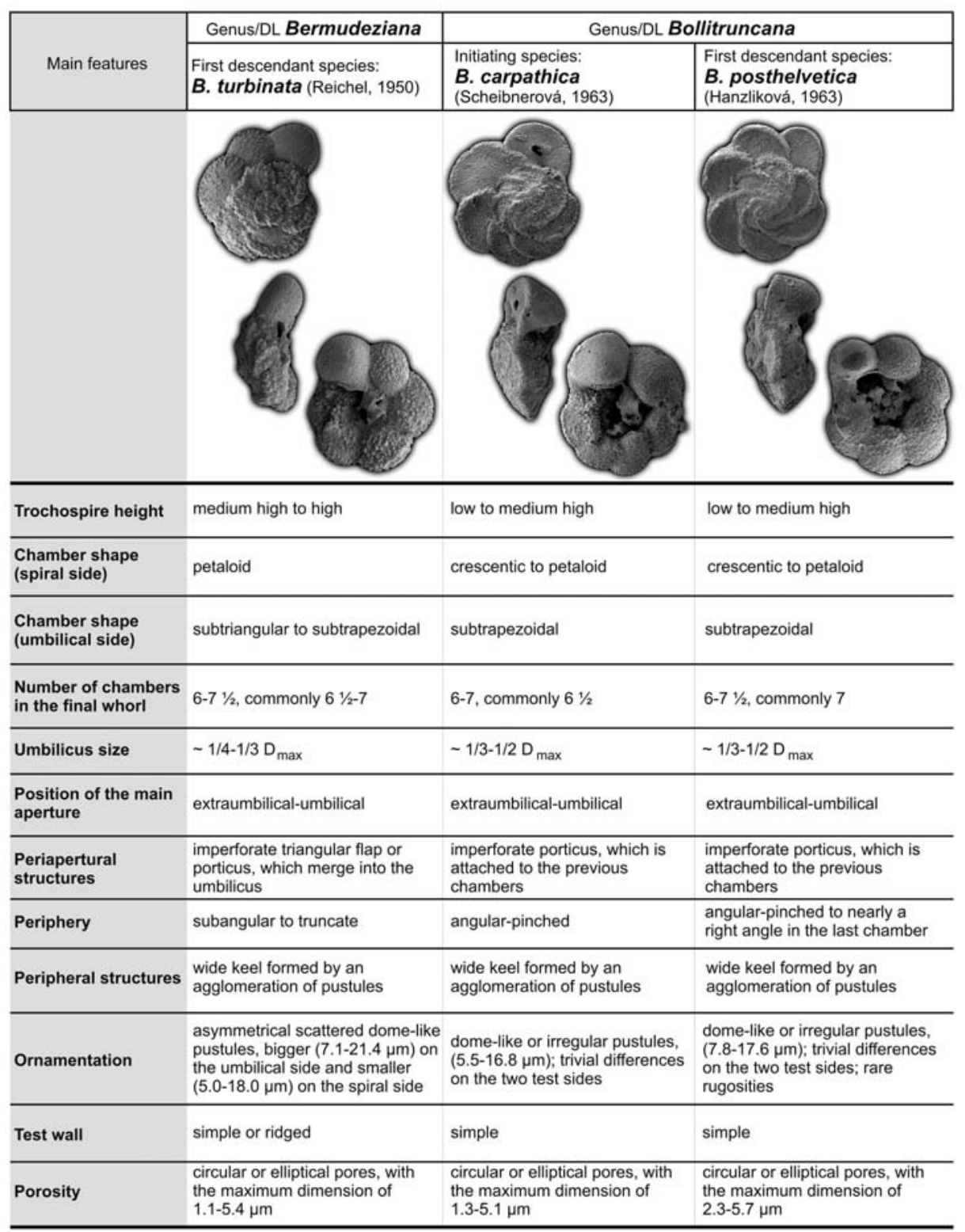

Fig. 5. Synthetic presentation of the main morphological features of the species included in the directional lineage Bollitruncana and their ancestor.

The directional lineage Bollitruncana evolved from Bermudeziana turbinata (Reichel, 1950) of the late Cenomanian-Turonian (Fig. 4). This lineage was initiated in the early Turonian, and the most significant difference between its initiating species ( $B$. carpathica) and the ancestor species (B. turbinata) is the increased convexity of the umbilical side. Additional differences include a slight increase in the umbilicus relative diameter, periapertural structures consisting of imperforate portici that attach to the previous chambers across the umbilicus, and development of crescentic-shaped chambers in the earlier portion of the final whorl (Fig. 5). There were not observed differences between the pustule size on the spiral and umbilical sides in any species of Bollitruncana; therefore it appears accurate to consider that the slight difference in the ornamentation of the spiral and umbilical sides of B. turbinata is a feature which was not further developed in the Bollitruncana lineage.

A new interval biozone of early Turonian age is defined between the FO of B. carpathica and FO of H. helvetica. The newly defined $B$. carpathica Biozone is situated between the $W$. archaeocretacea Biozone and H. helvetica Biozone.
Acknowledgments. The DSDP/ODP/IODP headquarters are thanked for allowing the resampling of the sections used in this study. Dr M. Schoel (Microscope and Imaging Facility, University of Calgary) is thanked for the professional and enthusiastic help during the SEM operations.

\section{R E F E R E N C E S}

Barr, F.T. 1972, Cretaceous biostratigraphy and planktic foraminifera of Libya. Micropaleontology, 18: 1-46.

Bellier, J.-P., Moullade, M. 2002, Lower Cretaceous planktonic foraminiferal biostratigraphy of the Western North Atlantic (ODP Leg 171B), and taxonomic clarification of key index species. Revue de Micropaléontologie, 45: 9-26.

Boersma, A. 1981, Cretaceous and Early tertiary foraminifers from Deep Sea Drilling Project Leg 62 sites in the Central Pacific. In Initial Reports of the Deep Sea Drilling Project (Stout, L.N., Ed.). United States Government Printing Office, Washington, D.C., 62: 377-395. 
Bolli, H.M. 1945, Zur Stratigraphie der Oberen Kreide in den höheren helvetischen Decken. Eclogae Geologicae Helvetiae, 37: 217-329.

Caron, M. 1966, Globotruncanidae du Crétacé supérieur du synclinal de la Guryère (Préalpes Médianes, Suisse). Revue de Micropaléontologie, 9: 68-93.

Caron, M. 1983, Taxonomie et phylogenie de la famille des Globotruncanidae. Zitteliana, 10: 677-681.

Caron, M. 1985, Cretaceous planktic foraminifera. In Plankton stratigraphy (Bolli, H.M., Saunders, J.B. \& Perch-Nielsen, K., Eds.). Cambridge University Press, Cambridge, p. 17-85.

Carsey, D.O. 1926, Foraminifera of the Cretaceous of Central Texas. University of Texas Bulletin, 2612: 1-56.

Donze, P., Porthault, B., Thomel, G. \& de Villoutreys, O. 1970, Le Sénonien inférieur de Puget-Theniers (AlpesMaritimes) et sa microfaune. Geobios, 3: 41-106.

Douglas, R.G. 1969, Upper Cretaceous planktonic foraminifera in northern California. Part 1 - Systematics. Micropaleontology, 15: 151-209.

Douglas, R.G. 1970, Planktonic foraminifera described from the Upper Cretaceous of California. Contributions from the Cushman Foundation for Foraminiferal Research, 21: $18-27$.

Douglas, R.G., Rankin, C. 1969, Cretaceous planktonic foraminafera from Bornholm and their zoogeographic significance. Lethaia, 2: 185-217.

Eichwald, C.E. von 1830, Zoologia specialis II. D.E. Eichwaldus, Vilnae, $323 \mathrm{p}$.

Franke, A. 1925, Die Foraminiferen der pommerschen Kreide. Abhandlungen aus dem geologisch-palaeontologischen Institut der Universität Greifswald, 6: 1-96.

Gandolfi, R. 1942, Ricerche micropaleontologiche e stratigrafiche sulla scaglia e sul flysch Cretacici dei Dintorni di Balerna (Canton Ticino). Rivista Italiana di Paleontologia, 48: 1-160.

Georgescu, M.D. 2009a, Upper Albian-lower Turonian nonschackoinid planktic foraminifera with elongate chambers: morphology reevaluation, taxonomy and evolutionary classification. Revista Española de Micropaleontología, 41: 255-293.

Georgescu, M.D. 2009b, On the origins of the Superfamily Heterohelicacea Cushman, 1927 and the polyphyletic nature of planktic foraminifera. Revista Española de Micropaleontología, 41: 107-144.

Georgescu, M.D. 2010a, Evolutionary classification of the Upper Cretaceous (Turonian-lower Campanian) planktic foraminifera with incipient meridional ornamentation. Journal of Micropaleontology, 29: 149-161.

Georgescu, M.D. 2010b, Origin, taxonomic revision and evolutionary classification of the late Coniacian-early Campanian planktic foraminifera with multichamber growth in the adult stage. Revista Española de Micropaleontología, 42: 59-118.

Georgescu, M.D. 2011, A new type of test wall in the Late Cretaceous (Late Santonian-Campanian) heterohelicid planktic foraminifera. Revue de Micropaléontologie, 54: 105-114.

Georgescu, M.D., Huber, B.T. 2009, Early evolution of the Cretaceous serial planktic foraminifera (late Albian-Cenomanian). Journal of Foraminiferal Research, 39: 335-360.

Georgescu, M.D., Quinney, A.E. \& Anderson, K.D. 2011, New data on the taxonomy, evolution and biostratigraphical significance of the Turonian-Coniacian
(Late Cretaceous) planktic foraminifer Huberella Georgescu, 2007. Micropaleontology, 57: 247-254.

Gradstein, F.M., Ogg, J.G. \& Smith, A.G. (Eds.) 2004. A Geologic Time Scale 2004. Cambridge University Press, Cambridge, $589 \mathrm{p}$.

Grosheny, D., Tronchetti, G. \& Schaaf, A. 1992, Présence de Sigalitruncana marianosi (Douglas, 1969) (Foraminiferida) dans le Turonien du Domaine Vocontien (SE France). Geobios, 25: 13-17.

Hagn, H., Zeil, W. 1954, Globotruncanen aus dem OberCenoman und Unter-Turon der Bayerischen Alpen. Eclogae Geologicae Helvetiae, 47: 1-60.

Hanzliková, E. 1963, Globotruncana helvetica posthelvetica n. subsp. from the Carpathian Cretaceous. Věstník Ústredního Ústavu Geologického, 38: 325-328.

Hay, W.H., DeConto, R.M., Wold, C.N., Wilson, K.M., Voigt, S., Schulz, M., Wold, A.R., Dullo, W, Ronov, A.B., Balukhovsky, A.N. \& Söding, E. 1999, Alternative global Cretaceous paleogeography. In Evolution of the Cretaceous Ocean-Climate System (Barrera, E., Johnson, C.C., Eds.). The Geological Society of America Special Publication, 332: 1-47, Boulder, Colorado.

Hofker, J. 1956, Die Globotruncanen von NordwestDeutschland und Holland. Neues Jahrbuch für Geologie und Paläontologie, Abhandlungen, 103: 312-340.

Huber, B.T., Leckie, R.M., Norris, R.D., Bralower, T.J. \& CoBabe, E. 1999, Foraminiferal assemblage and stable isotopic change across the Cenomanian-Turonian boundary in the subtropical North Atlantic. Journal of Foraminiferal Research, 29: 329-417.

Huber, B.T., Macleod, K.G. \& Tur, N.A. 2008, Chronostratigraphic framework for upper Campanian-Maastrichtian sediments of the Blake Nose (subtropical North Atlantic). Journal of Foraminiferal Research, 38: 162-182.

Ion, J. 1983, Étude micropaléontologique (foraminifères planctoniques) du Crétacé supérieur de Țara Bârsei (Carpates Orientales). Mémoires Institut de Géologie et de Géophysique, 31: 5-176.

Korchagin, V.I. 1982, Systematics of the globotruncanids. Byulletin Moskovskogo Obshchestva Ispytateley Prirody, Otdel Geologichskii, 57(5): 114-121.

Korchagin, O.A. 2001. Globotruncanid classification. Geologia $i$ Razvedka, 2: 17-22 [in Russian] fide O.A. Korchagin, 2003.

Korchagin, O.A. 2003, Classification of the Mesozoic planktonic foraminifers (superfamilies Planomalinacea, Rotaliporacea and Globotruncanacea). Trudy VNIGRI, 547: 1-89 [in Russian with English summary].

Lamolda, M.A. 1977a, Three new species of planktonic foraminifera from the Turonian of northern Spain. Micropaleontology, 23: 470-477.

Lamolda, M.A. 1977b, Los Marginotruncaninae del Turoniense Vasco-Cantabrico. Revista Española de Micropaleontología, 9: 381-410.

Loeblich, A.R. Jr., Tappan, H. 1961, Cretaceous Planktic foraminifera: Part I - Cenomanian. Micropaleontology, 7: 257-304.

Loeblich, A.R. Jr., Tappan, H. 1988, Foraminiferal genera and their classification. Van Nostrand Reinhold Company, New York, $970 \mathrm{p}$.

Marianos, A.W., Zingula, R.P. 1966, Cretaceous planktonic foraminifers from Dry Creek, Tehama County, California. Journal of Paleontology, 40: 328-342. 
Mornod, L. 1950, Les Globorotalidés du Crétacé supérieur $\mathrm{du}$ Montsalvens (Préalpes fribourgeoises. Eclogae Geologicae Helvetiae, 42: 573-596.

Morrow, A.L. 1934, Foraminifera and ostracoda from the Upper Cretaceous of Kansas. Journal of Paleontology, 8: 186-205.

Nauss, A.W. 1947, Cretaceous microfossils of the Vermillon area, Alberta. Journal of Paleontology, 21: 329-434.

Pessagno, E.A. Jr. 1967, Upper Cretaceous planktic foraminifera from the western Gulf Coastal Plain. Palaeontographica Americana, 5 (37): 245-445.

Petrizzo, M.R. 2000, Upper Turonian-lower Campanian planktonic foraminifera from southern mid-high latitudes (Exmouth Plateau, NW Australia): biostratigraphy and taxonomic notes. Cretaceous Research, 21: 479-505.

Petrizzo, M.R. 2001, Late Cretaceous planktonic foraminifera from Kerguelen Plateau (ODP Leg 183): new data to improve the Southern Ocean biozonation. Cretaceous Research, 22: 829-855.

Petrizzo, M.R., Huber, B.T. 2006, Biostratigraphy and taxonomy of late Albian planktic foraminifera from ODP Leg 171B (western North Atlantic Ocean). Journal of Foraminiferal Research, 36: 166-190.

Plummer, H.J. 1931, Some Cretaceous foraminifera in Texas. The University of Texas Bulletin, 3101: 109-203.

Reichel, M. 1950, Observations sur les Globotruncana du gisement de la Breggia (Tessin). Eclogae Geologicae Helvetiae, 42: 596-617.

Reiss, Z. 1957, The Bilamellidea, nov. superfam., and remarks on Cretaceous globotruncanids. Contributions from the Cushman Foundation for Foraminiferal Research, 8: 127-145.

Reuss, A.E. 1854, Beiträge zur Characteristik der Kreideschichten in den Ostalpen, besonders im Gosauthale und am Wolfgangsee. Denkschriften der Kaiserlichen Akademie der Wissenschaften, Mathematisch-Naturwissenschaftlische Klasse, 7: 1-156.

Robaszynski, F., Caron, M. 1995, Foraminifères planctoniques du Crétacé: commentaire de la zonation Europe-Mèditerranée. Bulletin de la Société Géologique de France, 6: 681-692.

Robaszynski, F., Caron, M., Dupuis, C., Amédro, F., González Donoso, J.-M., Linares, D., Hardenbol, J., Gartner, S., Calandra, F. and Deloffre, R. 1990. A tentative integrated stratigraphy in the Turonian of central Tunisia: formations, zones and sequential stratigraphy in the Kalaat Senan area. Bulletin du centre de Recherche, Exploration et Production, Elf-Aquitaine, 14, 213-384.

Robaszynski, F., Caron, M., Gonzalez Donoso, J.M., Wonders, A.A.H. \& The European Working Group on Planktic Foraminifera 1984, Atlas of Late Cretaceous Globotruncanids. Revue de Micropaléontologie, 26: 145-305.
Robaszynski, F., Caron, M. \& The European Working Group on Planktonic Foraminifera 1979, Atlas de Foraminifères planctoniques du Crétacé moyen (Mer Boréale et Téthys). Cahiers de Micropaléontologie, 2: 1-181.

Samuel, O., Salaj, J. 1962, Nové druhy foraminifer z kridey a paleogénu Západných Karpát. Geologické Prace, 62: 313-320.

Schacko, G. 1897, Beitrag über Foraminiferen aus der Cenoman-Kreide von Molzow in Mecklenburg. Archiv des Vereins der Freunde de Naturgeschichte in Mecklenburg (1896), 50: 161-168.

Scheibnerová, V. 1962, Stratigrafia strednej a vrchnej kriedy tetýdnej oblasti na základe globotruncaníd. Geologiký Sborník, 13: 197-226.

Scheibnerová, V. 1963, Some new foraminifera from the middle Turonian of the Klippen Belt of the West Carpathians in Slovakia. Geologický Sbornik, 14: 139-143.

Scheibnerová, V. 1968, Middle and Upper Cretaceous microbiostratigraphy of the Klippen Belt (West Carpathians). Acta Geologica et Geographica Universitatis Comenianae, Geologica, 17: 5-98.

Shipboard Scientific Party 1990, Site 762. In Proceedings of the Ocean Drilling Program, Initial Reports (von Rad, U., Haq, B.U. et al., Eds.). Ocean Drilling Program, College Station, 122: 213-288.

Shipboard Scientific Party 2098, Site 1050. In Proceedings of the Ocean Drilling Program, Initial Reports (Norris, R.D., Kroon, D. et al., Eds). Ocean Drilling Program, College Station, 171B: 93-169.

Sigal, J. 1948, Notes sur les genres de foraminifères Rotalipora Brotzen 1942 and Thalmanninella. Revue de l'Institut Français du Pétrole et Annales des Combustibles Liquides, 3: 95-103.

Sigal, J. 1952, Aperçu stratigraphique sur la micropaléontologie du Crétacé. Alger, $19^{\text {th }}$ International Geological Congress, Monographies regionales, $1^{\text {re }}$ ser., Algérie, 26: $1-52$.

Sturm, M. 1969, Zonation of Upper Cretaceous by means of planktonic foraminifera, Attersee (Upper Austria). Rocznik Polskiego Towarzystwa Geologicznego, 39: 103-132.

Trujillo, E.F. 1960, Upper Cretaceous foraminifera from near Redding, Shasta County, California. Journal of Paleontology, 34: 290-346.

Tur, N.A., Smirnov, J.P. \& Huber, B.T. 2001, Late AlbianConiacian planktic foraminifera and biostratigraphy of the northeastern Caucasus. Cretaceous Research, 22: 719-734.

Wonders, A.A.H. 1992, Cretaceous planktonic foraminiferal biostratigraphy, Leg 122, Exmouth Plateau, Australia. In Proceedings of the Ocean Drilling Program, Scientific Results (von Rad, U., Haq, B.U. et al., Eds.). Ocean Drilling Program, College Station, 122: 587-599. 


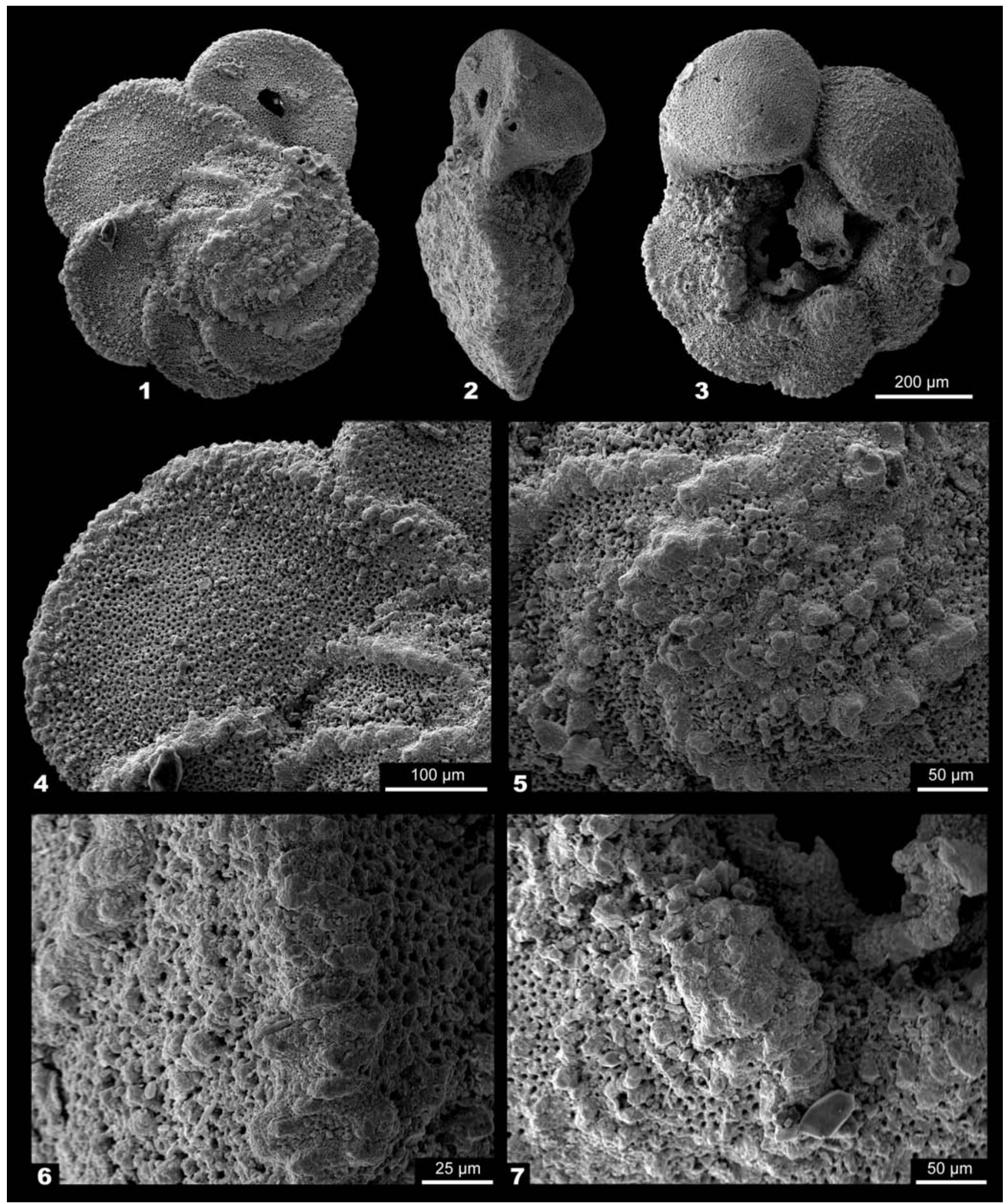

Plate I. Hypotype of Bollitruncana carpathica (Scheibnerová, 1963) from the Blake Plateau, western North Atlantic Ocean, Sample 171B-1050C-20-3, 38-41 cm.

1. Spiral side.
2. Edge view.

3. Umbilical side.

4. Detail micrograph of the spiral side (1) showing the scattered pustules concentrated in the keel proximity.

5. Detail micrograph of the spiral side (1) showing the ornamentation over the test earlier chambers.

6. Detail micrograph of the earliest chamber of the final whorl as seen in edge view (2) showing the well-developed peripheral keel.

7. Detail micrograph of the umbilical side (3) showing the periumbilical ridge consisting of agglomerated pustules on the earliest two chambers of the final whorl. 
PLATE II

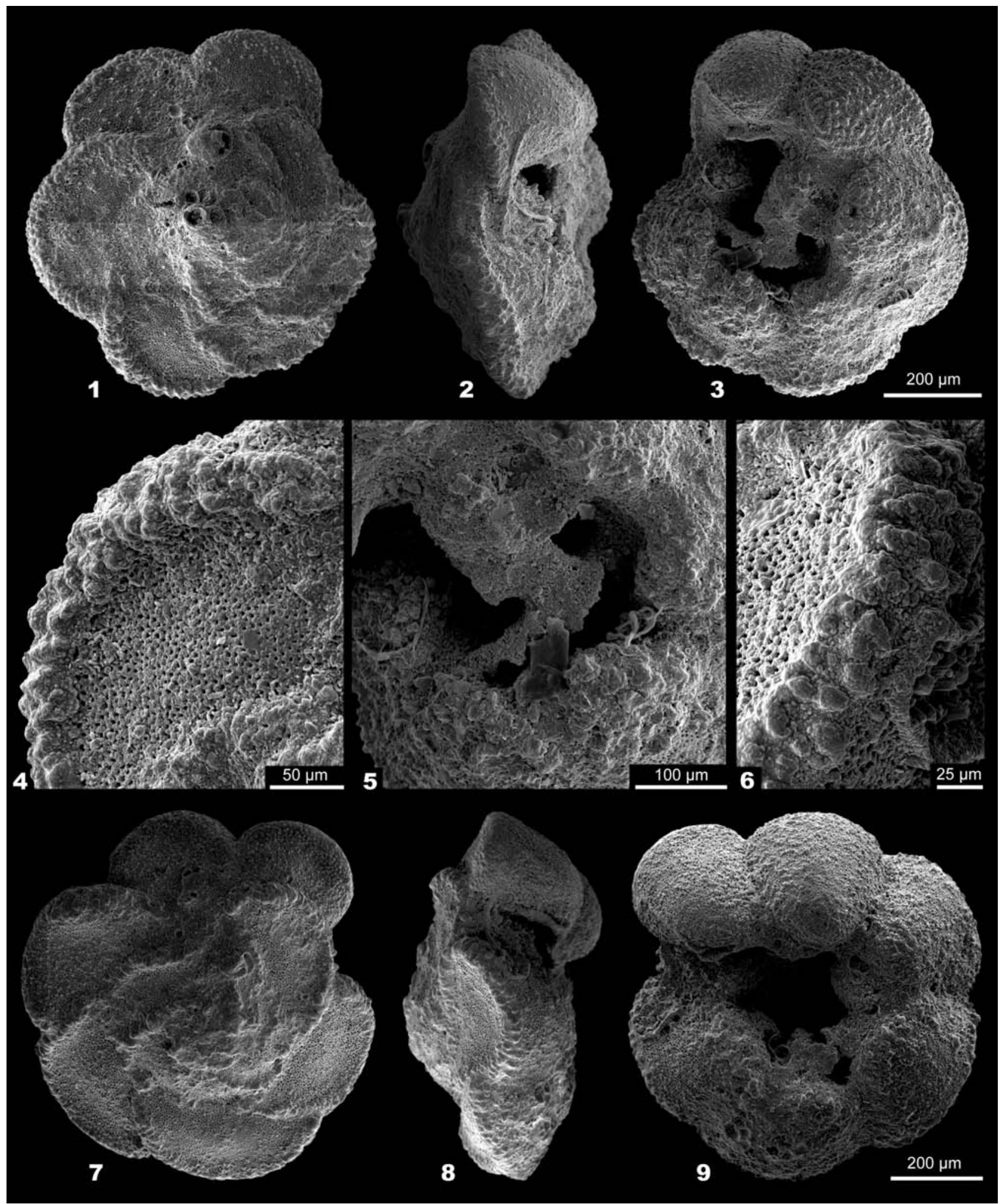

Plate II. Hypotypes of Bollitruncana carpathica (Scheibnerová, 1963) from the Blake Plateau, western North Atlantic Ocean, Sample 171B-1050C-20-3, 129-132 cm.

1. Spiral side.

2. Edge view.

3. Umbilical side.

4. Detail micrograph of the spiral side (1) showing the peripheral keel.

5. Detail micrograph of the umbilical side (3) showing the umbilical region and periapertural structures consisting of portici.

6. Detail micrograph of the edge view (8) showing the peripheral keel consisting of agglomerated and partly fused pustules, which result in elongate structures with axial orientation.

7. Spiral side.

8. Edge view.

9. Umbilical side. 


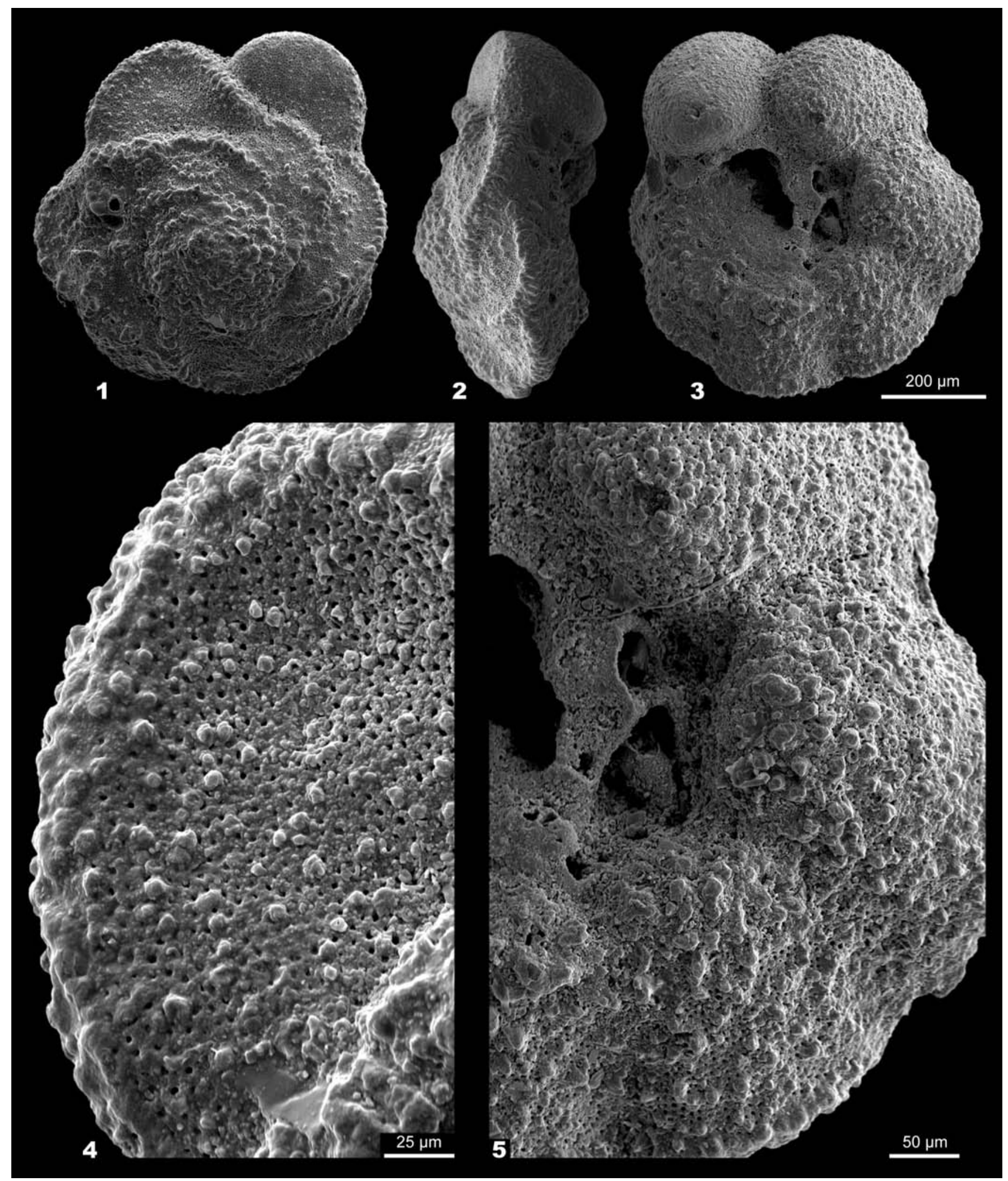

Plate III. Hypotype of Bollitruncana carpathica (Scheibnerová, 1963) from the Blake Plateau, western North Atlantic Ocean; Sample 171B$1050 \mathrm{C}-20-3,129-132 \mathrm{~cm}$.

1. Spiral side.

2. Edge view.

3. Umbilical side.

4. Detail micrograph of the spiral side (1) showing the ornamentation consisting of scattered pustules.

5. Detail micrograph of the umbilical side (3) showing the periapertural porticus and agglomerated pustules that do not form periumbilical ridges around the umbilicus. 
PLATE IV
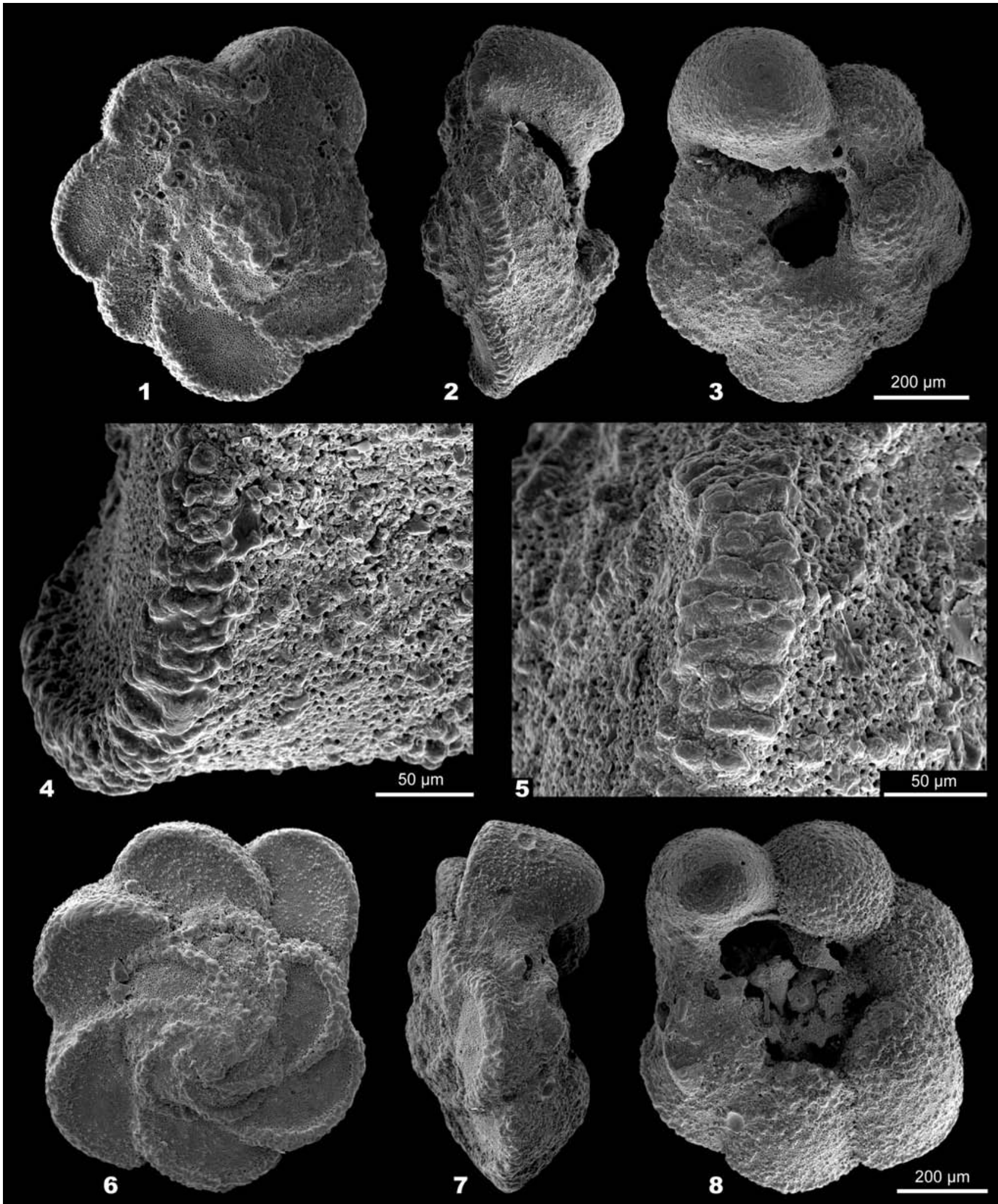

Plate IV. Hypotypes of Bollitruncana posthelvetica (Hanzliková, 1963) from the Blake Plateau, western North Atlantic Ocean; Sample 171B-1050C-20-3, 129-132 cm.

1. Spiral side.

2. Edge view.

3. Umbilical side.

4. Detail micrograph of the edge view (2) showing the well-developed peripheral keel and the axially elongate structures resulted from the pustule fusing.

5. Detail micrograph of the edge view (2) showing the well-developed peripheral keel and the axially elongate structures resulted from the pustule fusing.

6. Spiral side.

7. Edge view.

8. Umbilical side. 
PLATE V
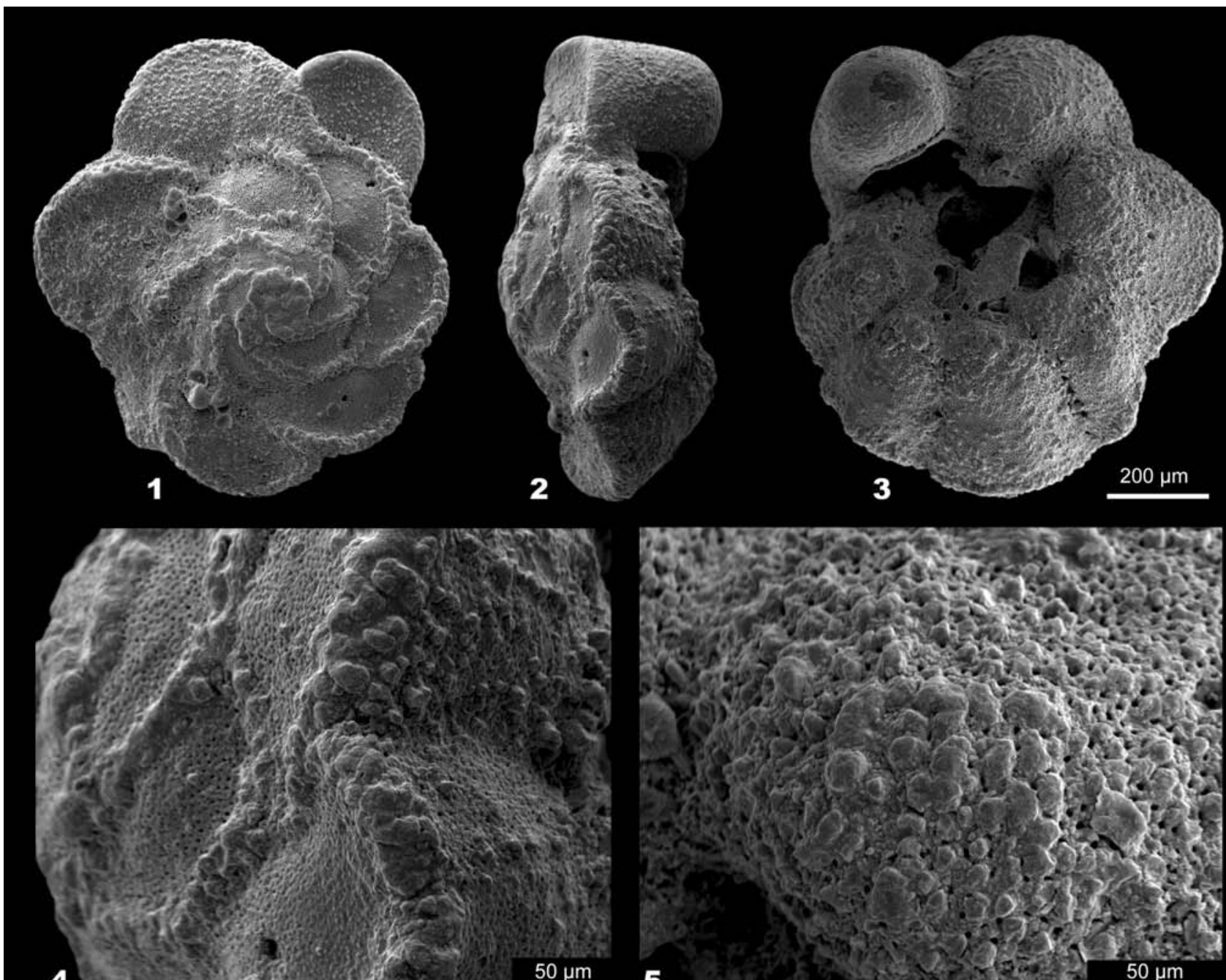

4
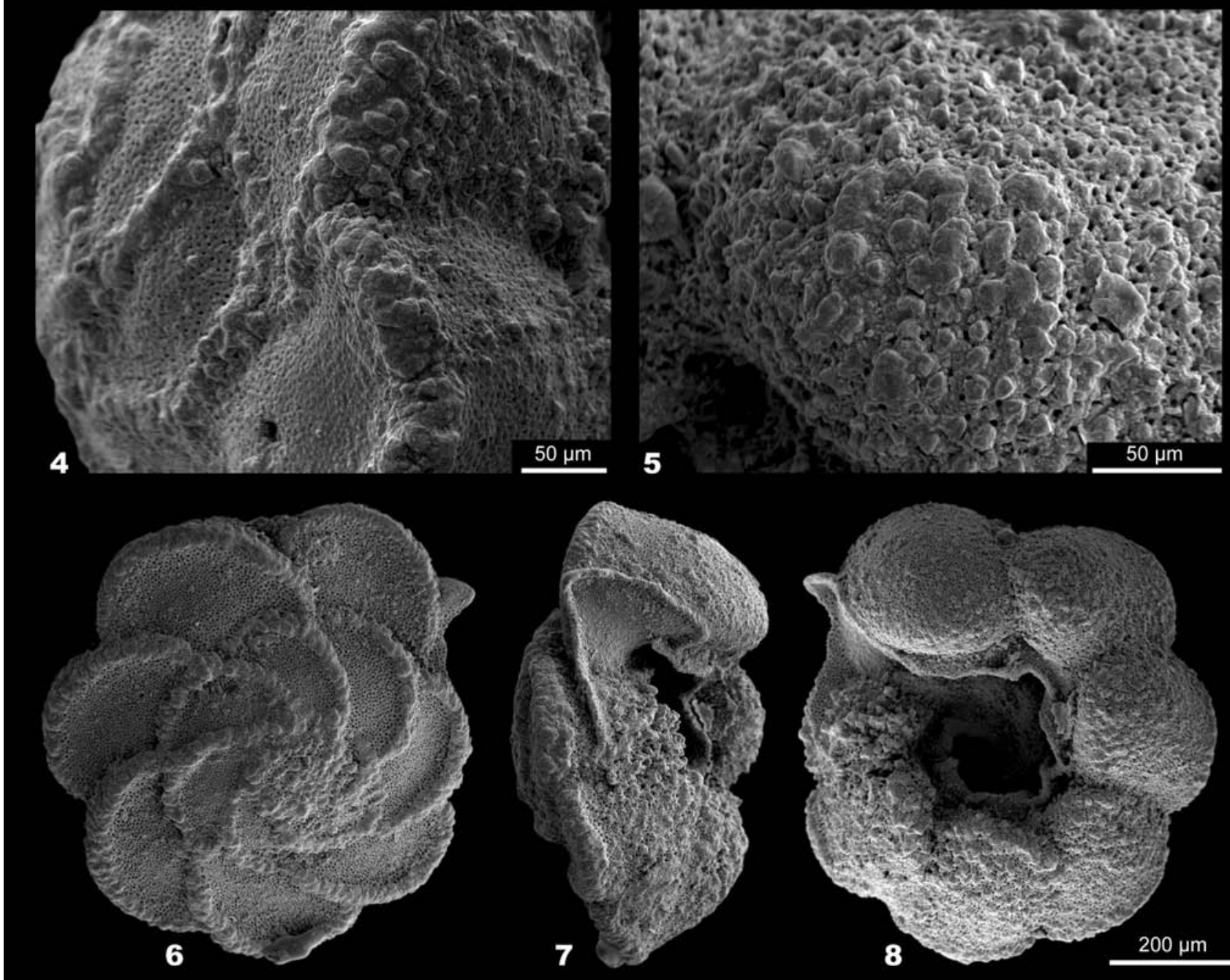

Plate V. Hypotypes of Bollitruncana posthelvetica (Hanzliková, 1963) from the Blake Plateau, western North Atlantic Ocean; Sample 171B-1050C-20-3, $129-132 \mathrm{~cm}(1-5)$ and Sample 171B-1050C-20-3, 38-41 cm (6-8).

1. Spiral side.

2. Edge view.

3. Umbilical side.

4. Detail micrograph of the edge view (2) showing the well-developed peripheral keel.

5. Detail micrograph of the umbilical side (3) showing the agglomerated pustules that do not fuse to form periumbilical ridges.

6. Spiral side.

7. Edge view.

8. Umbilical side.

Studia UBB Geologia, 2012, 57 (2), 3 - 16 